\title{
Determinants of non-performing loans in the banking sector in developing state
}

Determinants of nonperforming loans

School of Management, Huazhong University of Science and Technology, Wuhan, China

Asima Siddique

Department of Management Science, COMSATS University Islamabad, Islamabad, Pakistan, and

Zahid Sarwar

School of Business Administration, Dongbei University of Finance and Economics, Dalian, China

\begin{abstract}
Purpose - The size of non-performing loans (NPLs) plays a key role in the stability of the banking sector of a country. The factors that explain the NPLs contain very important information for banks. Studies in this regard with respect to developing states such as Pakistan have received little attention. This study aimed to scrutinize the determinants of NPLs observing a case of the banking sector in Pakistan over the period from 2005 to 2017. Design/methodology/approach - The sample consists of the banking sector (i.e., commercial banks) listed in Pakistan Stock Exchange over the period of 2005-2017. The banking factors, including profitability, operating efficiency, capital adequacy and income diversification, were evaluated. The estimations were done by regression modeling using random and fixed effects through STATA software.

Findings - Results show that the operating efficiency and profitability indicators have a negative association with NPLs but were statistically significant, while capital adequacy and income diversification have a negative association with NPLs but were statistically insignificant.

Research limitations/implications - The present study has considered limited banking indicators as determinants of NPLs and was limited to a specific time period from 2005 to 2017.

Originality/value - The study is an attempt to investigate various banking factors that affect the NPLs with respect to developing economies such as Pakistan.
\end{abstract}

Keywords Non-performing loans (NPLs), Banking factors, Panel data models, Pakistan

Paper type Research paper

\section{Introduction}

Financial crises are one of the most immediate and important issues for the banking sector globally, especially in developing countries. Over the past few years, remarkable financial crises have been witnessed in numerous countries. The latest financial crises were faced in the US subprime mortgages due to the financial credit crunch that occurred in 2007 and 2008, resulting in financial crises and financial market instability. Earlier in 1997, the developing countries in East Asia have suffered the financial crises in the form of a significant outflow of foreign investment (Soedarmono et al., 2011). Monetary crises are highly marked by the ascent of non-performing loans (NPLs) in banking advances. After the global crises, NPLs are

(C) Muhammad Asif Khan, Asima Siddique and Zahid Sarwar. Published in Asian Journal of Accounting Research. Published by Emerald Publishing Limited. This article is published under the Creative Commons Attribution (CC BY 4.0) licence. Anyone may reproduce, distribute, translate and create derivative works of this article (for both commercial and non-commercial purposes), subject to full attribution to the original publication and authors. The full terms of this licence may be seen at http:// creativecommons.org/licences/by/4.0/legalcode

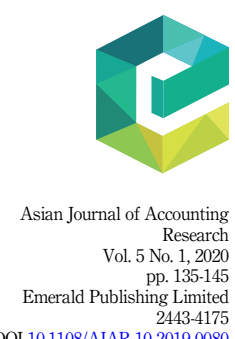

Received 23 October 2019 Revised 11 November 2019 27 December 2019

19 January 2020

26 February 2020

4 March 2020

Accepted 24 March 2020

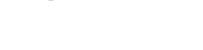

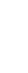


AJAR 5,1

mainly under the eyes of government and banking management since they are considered with the failure and crises of the banking system (Ghosh, 2015). This phenomenon is most crucial to countries that highly rely on banks as monetary intermediaries that assign funds throughout the country's economy. In banking-centered economic system, banks play a key part in the sustainability of the banking system and are known as the primary source of funding, as the capital markets of these countries are still emerging (Moradi et al., 2016).

Advances that remain unpaid are called NPLs. International Monterey Fund (IMF) stated that loans would be considered NPLs if they do not produce interest and principal amount for a minimum of 90 days Alton and Hazen (2001) stated that loans become NPLs if the principal amount and its interest are not yet paid on the maturity date and are not anticipated in future dates. The main reasons for high NPLs are weak credit procedure, low capable credit specialists, high markup spreads, low credit principles and lack of monitoring policy of the borrowers. NPLs are major indictor to measure credit risk that affects the banking system of the country. Handley (2010) stresses that NPLs can be used as an indicator of banking crises as it affects the economic growth of the nation by decreasing credit development (Ivanovic, 2016). A low level of NPLs shows a strong monetary system of the country while high NPLs indicate a weak financial position. The increasing level of NPLs will first affect the commercial banks in the long run then it will affect the financial position of the economy in the country (Souza and Feijó, 2011). The increasing drift of NPLs will affect the banking efficiency resulting in banking crises (Vouldis and Louzis, 2018). The NPLs will block the interest revenue, reduce investment openings as well as develop liquidity crises in the financial system, which results in bankruptcy problem and weak economic system. Thus, it is necessary to identify the factors that affect NPLs to decrease the level of NPLs for financial stability and economic goals (Stijepović, 2014).

Michael (2006) stated that NPLs affect the overall routine of the banking sector, thus threatening the bankruptcy of the banking sector. A high level of NPLs directly affects the overall financial performance of the banks (Berger and DeYoung, 1997). Fofack (2005) stated that the leading cause of economic crises in African countries is due to the high level of NPLs in banks. In case of Pakistan, the State Bank of Pakistan (SBP) controls the overall banking structure of the country and is responsible for the smooth regulations of banking sector. The reports of SBP shows that NPLs ratio is increasing rapidly over time. In 2005, the NPLs ratio was $6.7 \%$, which reached to $14.3 \%$ in 2010 and is still moving upward. The effects of NPLs will result in dividend payments, high interest rates and low levels of investments resulting in the lower economic development of the country.

\section{Literature review}

Researchers have identified various elements that affect the NPLs, including income diversification, profitability, capitalization and operating efficiency. However, the relationship between NPLs and these factors is not clear. Some researchers concluded that these factors have positive relationships, while others reject their results.

\subsection{Return on assets (ROA)}

Godlewski (2008) investigated the association between NPLs and return on assets (ROA), and he stated that the lower the rate of ROA, the higher would be NPLs and vice versa. Boudriga et al. (2010a) confirmed from their study that there is a negative association between ROA and NPLs. They concluded that when the ROA decreases, then the bank starts to make investments in highrisk projects, and as a result the level of NPLs increases. Makri et al. (2014) showed that there is a negative affiliation between ROA and NPLs, while Ahmad (2015) stated that there is a positive association between ROA and NPLs. Berger and DeYoung (1997) concluded that banks with a 
high level of income are less involved in risky investments that can lead to loan nonpayment in the future, thus concluded that there is a negative association between NPLs and bank profitability. Rajan (1994) stated that credit policy is not made to make a profit but also to make good reputation; therefore, the managements of the banks try to make such credit policy from current earning to cover the loan defaults in following periods. Thus, it makes a positive relationship between NPLs and the profitability of the banks.

Godlewski (2008) stated that there is a direct relationship between NPLs and ROA; the lower the ROA, the higher will be NPLs and vice versa. Ahmad and Bashir (2013) affirm that ROA and NPLs have direct association. Hue (2015) concluded from her study that the growth rate of loans increased the NPLs for Vietnamese banks from 2009 to 2012. Kirui (2014) stated that the impact of NPLs on the profitability of commercial banks in Kenya was negative, and NPLs decreased the profitability of the banks from 2004 to 2013. Dimitrios et al. (2016) investigated various determinants of NPLs in euro banking system and concluded that ROA has a significant impact upon NPLs. Rachman et al. (2018) examined various banking factors that affected the NPLs in Indonesia and concluded that the high profitability of banks has lower NPLs due to their better advancing activity and effective credit supervision system. Kumar and Kishore (2019) studied various banking and microeconomic factors as elements of NPLs in the banking system of the UAE and revealed that ROA has an insignificant association with NPLs. Based on earlier argument, we suppose that:

H1. Return on assets has a positive association with NPLs.

\subsection{Efficiency of bank}

When the bank performs all its business activities at a relatively low cost, then we can say that the bank is efficiently doing its job. Berger and DeYoung (1997) concluded that decrease in the cost efficiency of commercial banks in the United States would affect the increase in future loan defaults. This is faced by those managers who are unable to control operating expenses and loan portfolio management. However, in another study, when the efficient banks are studied, an increase in cost efficiency is followed by slog of loan defaults giving the skimping hypothesis (an increase in loan defaults happened when banks decided to spend less amount on underwriting and have a close look on loans in short run and bear the risk of having loan performance problems in near future).

Ekanayake and Azeez (2015) studied the factors that affected the NPLs in the banking sector of Sri Lanka for the period between 1999 and 2012 and concluded that NPLs have a positive correlation with the size of bank and efficiency of the bank. Benthem (2017) examined the relationship between operating efficiency, capitalization and NPLs in commercial banks, and the result indicates that operating efficiency increases the higher level of NPLs, which proposes that management conducts effect NPLs. Fiordelisi et al. (2011) examined the various factors that increased the risk level in the EU banks and concluded that decreasing efficiency increases the risk level of banks in future. Furthermore, the efficiency and performance factors have an influence on NPLs in the Greek banking sector (Louzis et al., 2012). Rachman et al. (2018) stated that operating efficiency does not influence NPLs. So we propose that:

H2. Bank efficiency has a positive association with NPLs.

\subsection{Bank capital}

The effect of bank capital on NPLs is in the opposite direction. On one side, the incentive and encouraging managers of low capitalized banks tend to get involved in high-risk investments and give loans that are issued without proper credit rating and monitoring (Keeton, 1999). As a result of these activities, the rise in loan default occurs showing the negative relationship between bank capital and NPLs. On the other side, banks with a high level of capital tend to
Determinants of nonperforming loans 
AJAR 5,1

\section{8}

give loans easily as they know that due to these loans banks are not going to be bankrupt and fail; therefore, banks are highly engaged with these kinds of risky credit activities suggesting a positive association between capital and NPLs (Rajan, 1994).

Capital adequacy ratio (CAR) shows the ability of an organization to face abnormal losses and to survive that situation. Hu and Chiu (2004) concluded from their study that bank size has a negative impact on NPLs when banks give risky advances. Makri et al. (2014) also stated that there is a negative association between CAR and NPLs. Constant and Ngomsi (2012) stated that NPLs and CAR are having a positive association with each other. Amuakwa and Boakye (2015) studied the various banking factors that effected the NPLs in Ghana and revealed that microeconomic factors have a negative impact on NPLs while bank capital has a positive impact on NPLs. Kumar and Kishore (2019) stated that concerning banking factors, the NPLs and CAR are having a negative association in the banking sector. Koju et al. (2018) conducted a study on the banking sector of Nepal and concluded that CAR has a negative relationship with NPLs. Keeping in view the diverse views and disagreements among researcher, we suppose that:

H3. Bank capital has a positive association with NPLs.

\subsection{Income diversification}

There are two types of earnings received by the banks: one is from lending activities and the other is from noninterest activities, that is, trading and derivative transaction. Banks with more income other than interest income are more careful and try to lower their risk by investing very less in high-risk investments. Therefore, these banks have better loan performance showing the inverse relationship between NPLs and income diversification (Ghosh, 2015). Hu (2002), on the other hand, stated that there is no relationship between NPL and income diversification. Louzis et al. (2012) investigated various banking and microeconomic factors as determinants of NPLs such as leverage ratio, ROA, CAR and noninterest income in different Greek banks and concluded that ROA has a negative impact while noninterest income has a positive impact upon NPLs. Rachman et al. (2018) studied the various banking factors affecting the NPLs in Indonesia including income diversification, bank capital and other banking factors. Their study revealed that these factors do not influence NPLs; however, a negative association was found between NPLs and income diversification. Based on the results as mentioned earlier of the studies, we suppose that (see Table 1):

H4. Income diversification has a positive association with NPLs.

\section{Methodology}

Banking data are retrieved from balance sheets and income statements of the individual banks. Nine different types of banks are used for analysis from the time period ranging from

Table 1.

Summary of literature review

\begin{tabular}{lll}
\hline Variables & Relationship with NPLs & References \\
\hline Return on assets & Positive & Dimitrios et al. $(2016)$ \\
& Negative & Rachman et al. $(2018)$ \\
Bank efficiency & Positive & Benthem (2017) \\
& No effect & Rachman et al. $(2018)$ \\
Bank capital & Negative & Koju et al. (2018) \\
& Negative & Makri et al. (2014) \\
Income diversification & No effect & Rachman et al. (2018) \\
& Negative & Ghosh (2015)
\end{tabular}


2005 to 2017. This time period is taken because it has never been considered in previous studies to assess the NPLs in the banking sector of Pakistan. Previous studies have only considered the time period ranging from 2000 to 2012 in different studies by (Badar and Yasmin Javid, 2013; Mehmood et al., 2013; Jameel, 2014). Studies on assessing NPLs considering data from recent years are lacking. Therefore, in this study, we attempted to assess the determinants of NPLs from the time period ranging from 2005 to 2017. This time period is considered due to the availability of sufficient data for the analysis of variables. One advantage of the panel data is that it decreases the multicollinearity among variables and also enlarges the number of observations and degree of freedom (Boudriga et al., 2010b). Panel data is also helpful in identifying the bank-specific factors and unknown observation differences among individual banks (Ghosh, 2015). In this study, we considered the banking sector of Pakistan. The NPLs are considered as a dependent variable and measured as NPLs ratio, while profitability, income diversification, capital and operating efficiency were considered independent variables.

\subsection{Definitions of variables}

Definitions of dependent and independent variables under study are given as follows.

3.1.1 Non-performing loans (NPLS). NPLs are the loans that remain unpaid. IMF stated that a loan is considered as NPL if it does not generate interest and the principal amount for a minimum of 90 days Alton and Hazen (2001) stated that loans become NPLs if the full payment of principal amount and interest is not done on the due date and is no longer expected in future dates. In this study, the NPLs were measured as the ratio of NPLs to total loans.

3.1.2 Return on assets (ROA). ROA is used to measure the profitability of the banks and measured as the net income to total assets (Rajan, 1994). High ROA shows that the financial position of the banks is stable, and they are not interested in investing in risky loans because of less pressure to generate income.

3.1.3 Income diversification. Income diversification means that the banks get income from sources other than interest earnings, and it is measured as noninterest income divided by total income (Louzis et al., 2012).

3.1.4 Bank capital. The CAR measures the soundness level of the banks. It represents the ability of the organization to stand in case of abnormal losses and also shows the strength and stability of the organization in the time of crises. Firms should maintain a minimum CAR for their survival. The ratio of total equity to total assets is used for its measurement (Makri et al., 2014).

3.1.5 Bank efficiency. Operating efficiency can be defined as the cost function that assumes that banks' income boosts, or the other way around, it is not about increasing income, but also about reducing cost at all level of output (Daley and Matthews, 2009). Moreover, it is measured as noninterest expense divided by noninterest income.

STATA statistical software was used for analyzing the data. For analyzing the panel data, various types of models are available such as common-, fixed- and random-effect models. The common effect model is one of the simplest models that ignore the effect of individual banks and time with the assumption that all individual banks are homogenous, and their nature is the same over time (Gujarati and Dawan, 2015). So the common-effect model has the same constant and coefficients across individual banks and overtime periods.

$$
Y_{t}=\alpha+\beta X_{t}+\varepsilon_{t}
$$

The fixed-effect model is used by controlling unnoticed heterogeneity over time and allowing variation in behavior among individual banks, so the modal allows different constants for individual banks, but the coefficients are fixed over time.
Determinants of nonperforming loans 
AJAR

5,1

$$
Y_{i t}=\alpha+\beta X_{i t}+\varepsilon_{i t}
$$

Gujarati and Dawan (2015) stated that random effect is estimated by allowing time variation to individual banks. Therefore, the random-effect model has fixed coefficients, and in random effect, the constant consists of a random component.

$$
Y_{i t}=\alpha+\varepsilon+\beta X_{i t}+\varepsilon_{i t}+\theta_{i t}
$$

In this study, we investigated the association between NPLs and various independent variables in panel regression. Since panel regression combines cross section and time series so the residuals will likely to correlate with time and individual banks; therefore, the ordinary least square will be biased.

The bank-specific model is given as follows:

$$
\mathrm{NPL}_{i t}=\beta_{0}+\beta_{1} \mathrm{ROA}_{i t}+\beta_{2} \mathrm{CAP}_{i t}+\beta_{3} \mathrm{DIV}_{i t}+\beta_{4} \mathrm{EF}_{i t}+\mu_{i t}
$$

Where NPL ${ }_{\text {it }}$ denotes the NPL ratio for bank $i$ in time period $t . \beta_{0}$ denotes the intercept. $\mathrm{ROA}_{i t}$ shows the profitability of the bank of the individual banks in time period $t . \mathrm{EF}_{i t}$ denotes the operating efficiency of the bank in time period $t . \mathrm{CAP}_{i t}$ represents the capital of the individual bank for time period $t$. while $\mathrm{DIV}_{i t}$ shows the income diversification of the bank for time period $t . t$ represents the time period from 2005 to 2017, and I represents the banks, while $\beta_{1 \text {, }}$ $\beta_{2}, \beta_{3}$ and $\beta_{4}$ represent respective coefficient terms.

\section{Results}

\subsection{Descriptive statistics}

This section presents the descriptive statistics of both dependent and independent variables, that is, NPLs, profitability, capital, operating efficiency and income diversification of commercial banks (see Table 2) listed in SBP over the time period of 2005-2017.

In this study, the total number of observations was 117. Table 2 shows that the mean values for NPL, profitability, efficiency ratio, capital and income diversification were 4.61, $2.05,47.36,7.77$ and 678.37 , respectively. The standard deviation for NPL was 4.57 , with a minimum value of -2.48 and a maximum value of 20.24 . The minimum value for profitability (ROA) was -5.02 , with a maximum value of 13.5 and a standard deviation of 3.14. However, the standard deviation for operating efficiency was 23.00 , with a minimum value of 0.9743 and maximum value of 106.21. In the case of bank capital, the minimum and maximum values were 1.28 and 18.64, with standard deviation of 3.24. For variable income diversification, the maximum and minimum values were 7087.9 and 1037.05 , with standard deviation of 949.34, respectively.

\subsection{Correlation matrix}

The correlation matrix between dependent variables and independent variables is shown in Table 3.

Table 2.

Descriptive statistics of all variables

\begin{tabular}{lccccc}
\hline Variables & NPL & ROA & EF & CAP & DIV \\
\hline Mean & 4.6146 & 2.0593 & 47.36 & 7.7715 & 678.37 \\
Maximum & 20.24 & 13.5 & 106.214 & 18.64 & 7087.9 \\
Minimum & -2.4787 & -5.029 & 0.9743 & 1.28 & 1037.05 \\
Standard deviation & 4.57 & 3.14 & 23.006 & 3.248 & 949.34 \\
Number of observations & 117 & 117 & 117 & 117 & 117 \\
\hline
\end{tabular}


Table 3 shows the correlation matrix between the dependent and independent variables. No problem of multicollinearity between dependent and independent variables was found because the values of all the variables were less than 0.80 , as suggested that there will be no multicollinearity if the value is less than 0.80 between variables.

\subsection{Regression analysis}

Both fixed- and random-effect techniques are used on the observed data. As the data have both properties such as time series and cross section, therefore, both techniques were used during the analysis. Because these techniques have the properties of both time base change and to examine individual entity.

4.3.1 Random-effect model. The $R$ square for random-effect panel least square was 0.2703 . Thus, $27 \%$ NPLs are explained by independent variables (see Table 4). ROA was found to have a negative relation with NPLs and was statistically significant. Operating efficiency (EF) was also observed with negative relationship with NPLs with $p$-value less than $5 \%$. Therefore, we can say that it has a significant impact on NPLs. Moreover, both the CAP and DIV showed negative relationship with NPLs but were not statistically significant because their $p$-value is greater than $0.05 \%$.

4.3.2 Fixed-effect model. The $R$ square value was 0.261 , so $26 \%$ NPLs were explained by the independent variables. Table 5 shows that ROA is having negative impact on NPL and statistically nonsignificant because the $p$-value for ROA is greater than $0.05 \%$. The EF has a negative relationship with NPL but was statistically significant. The relationship
Determinants of nonperforming loans

\begin{tabular}{|c|c|c|c|c|c|c|}
\hline Variables & NPL & $\mathrm{ROA}$ & $\mathrm{EF}$ & CAP & DIV & \\
\hline NPL & 1 & & & & & \\
\hline ROA & $-0.2437^{*}$ & 1 & & & & \\
\hline $\mathrm{EF}$ & -0.4337 & -0.0091 & 1 & & & \\
\hline CAP & -0.0920 & 0.4085* & -0.1016 & 1 & & Table 3. \\
\hline DIV & $-0.2309 *$ & -0.0491 & $0.2530^{*}$ & -0.0843 & 1 & Correlation analysis \\
\hline
\end{tabular}

\begin{tabular}{|c|c|c|c|c|c|}
\hline \multirow[b]{2}{*}{ Model 1} & \multicolumn{2}{|c|}{ Unstandardized coefficients } & \multirow[b]{2}{*}{$t$-Value } & \multirow[b]{2}{*}{ Significant value } & \\
\hline & $B$ & Standard error & & & \\
\hline Constant & 0.546 & 0.178 & 3.06 & 0.02 & \\
\hline ROA & -0.3412 & 0.1289 & -2.65 & 0.008 & Table 4. \\
\hline $\mathrm{EF}$ & -0.0804 & 0.0166 & -4.83 & 0.00 & Random-effect panel \\
\hline CAP & -0.0699 & 0.1254 & -0.56 & 0.577 & least square $(R$ \\
\hline DIV & -0.0006 & 0.0004 & -1.72 & 0.08 & square $=0.27)$ \\
\hline
\end{tabular}

\begin{tabular}{|c|c|c|c|c|c|}
\hline \multirow[b]{2}{*}{ Model 2} & \multicolumn{2}{|c|}{ Unstandardized coefficients } & \multirow[b]{2}{*}{$t$-Value } & \multirow[b]{2}{*}{ Significant value } & \\
\hline & $B$ & Standard error & & & \\
\hline Constant & 11.33 & 1.34 & 8.41 & 0.000 & \\
\hline ROA & -0.2251 & 0.1359 & -1.66 & 0.101 & Table 5. \\
\hline $\mathrm{EF}$ & -0.0910 & 0.0167 & -5.42 & 0.00 & Fixed-effect panel least \\
\hline CAP & -0.1692 & 0.1330 & -1.27 & 0.20 & square $(R$ \\
\hline DIV & -0.0009 & 0.0004 & -2.25 & 0.02 & square $=0.26$ ) \\
\hline
\end{tabular}


AJAR 5,1

between CAP and NPL was negative and insignificant while the association between NPL and DIV is also negative but statistically significant because the $p$-value for DIV is less than $0.05 \%$.

4.3.3 Hausman's test. Hausman's test was used to select the most appropriate model from the fixed-effect and random-effect least square models (see Table 6). The null hypothesis is fixed-effect model while the alternate is a random-effect model, so results show that the $p$ value is insignificant. Therefore, we should select the random-effect least square model.

\subsection{Discussions}

Comparing with the studies conducted by various researchers on NPLs and bank-specific factors, our results show that there is a negative association between ROA and NPLs. The negative relationship between NPLs and profitability opposes the work done by (Rajan, 1994), who concluded the positive association between NPLs and profitability. However, the negative relationship is supported by (Berger and DeYoung, 1997), who stated that there is a negative association between NPLs and profitability. The results indicate a negative association between operating efficiency and NPLs for the specified time period. Operating efficiency has a negative relationship with NPLs, which supports the work done by (Berger and DeYoung, 1997), affirming the negative influence of operating efficiency on NPLs. However, some researchers oppose this negative association between operating efficiency and NPLs. Banking capital plays a key role in the success of banking. The outcome of results showed negative association between banking capital and NPLs. The results also showed negative association between bank capital and NPLs, which supports the results of (Rajan, 1994), who affirmed that there is negative association between bank capital and NPLs. Based on these results, it is concluded that there is a negative association between income diversification and NPLs, while the association between income diversification and NPLs is negative, which is supported by (Ghosh, 2015), who stated that there is a negative association between NPLs and income diversification.

\subsection{Conclusion}

This study concludes that the banking sector plays a key role in country's economy and is considered as the backbone in the financial transaction of the country. Compared to other countries, Pakistan's banking sector is also facing the problems of NPLs. The main aim of this study was to understand the banking factors that determine the NPLs in the banking sector of Pakistan. The random-effect panel least square model shows that profitability has a negative and significant impact upon NPLs. This indicates that the profitability of the banks is strongly influenced by the increase in the amount of NPLs. The level of NPLs is increased by various factors such as political interference in the banking system of the country and wrong investment decisions by the management. Based on the result, we concluded that the policymakers should acquire a strong financial position of banks by making more profits; by doing so the banks will be capable of doing proper loan management processes such as to check the creditworthiness of the creditors. As a result, the value of NPLs will go lower and

Table 6.

Hausman's test

\begin{tabular}{lcrrr}
\hline Variables & Fixed & Random & Difference & S E \\
\hline ROA & -0.2251459 & -0.3412454 & 0.1160995 & 0.0429726 \\
EF & -0.0910081 & -0.0804805 & -0.0105277 & 0.0020223 \\
CAP & -0.1692403 & -0.0699327 & -0.0993077 & 0.0443362 \\
DIV & -0.000934 & -0.0006957 & -0.0002384 & 0.000082 \\
Chi2 $=34.92 ;$ Prob $>$ Chi2 $=0.2436$ & & & \\
\hline
\end{tabular}


lower, and banks will gain more profits. Similarly, the bank's top management must invest in useful things so that there is no chance of loss, and as a result, the banks will earn more profits. In case of CAR and income diversifications, both have a negative association with NPLs. The results also showed that the operating efficiency has negative and significant impact upon NPLs. Therefore, when the banking sector expenses are more as compared to income, the banks will have more expenses compared to revenue and the overall profit will be low, influencing NPLs of the banks. So for the better financial position of the banking sector, the operating efficiency should be maintained as low as possible.

\subsection{Limitations and future research directions}

The present study has considered limited banking indicators as determinants of NPLs and was limited to a specific time period from 2005 to 2017. Therefore, future studies should consider more data sets and variables as determinants of the NPLs to perform more in-depth analysis. Economic factors can also be used in future studies along with banking variables as elements of NPLs. Moreover, cross-cultural influences on NPLs can also be checked. The research can be done in other developing countries to examine the effect of banking factors on NPLs.

\section{References}

Ahmad, F. (2015), "Explanatory power of bank specific variables as determinants of non-performing loans: evidence from Pakistan banking”, World Applied Sciences Journal, Vol. 22 January 2013, pp. 1220-1231, doi: 10.5829/idosi.wasj.2013.22.09.1908.

Ahmad, F. and Bashir, T. (2013), "Explanatory power of bank specific variables as determinants of non-performing loans: evidence form Pakistan banking sector", World Applied Sciences Journal, Vol. 22 No. 9, pp. 1220-1231.

Alton, R.G. and Hazen, J.H. (2001), “As economy flounders, do we see a rise in problem loans”, Federal Reserve Bank of St. Louis, Vol. 11 No. 4, pp. 45-65.

Amuakwa-Mensah, F. and Boakye-Adjei, A. (2015), "Determinants of non-performing loans in Ghana banking industry", International Journal of Computational Economics and Econometrics, Inderscience Enterprises, Vol. 5 No. 1, pp. 35-54.

Badar, M. and Yasmin Javid, A. (2013), "Impact of macroeconomic forces on nonperforming loans: an empirical study of commercial banks in Pakistan", WSEAS Transactions on Business and Economics, Vol. 10 No. 1, pp. 40-48.

Benthem, C.S. (2017), The Relation Among Non-performing Loans, Operating Efficiency, and Capitalization in Commercial Banking, University of Twente, Enschede, Netherlands.

Berger, A.N. and DeYoung, R. (1997), "Problem loans and cost efficiency", Journal of Banking and Finance, Vol. 21, pp. 1-28.

Boudriga, A., Taktak, N.B. and Jellouli, S. (2010a), "Bank specific, business and institutional environment determinants of banks nonperforming loans: evidence from mena countries", Economic Research Forum, Working Paper, pp. 1-28.

Constant, F.D. and Ngomsi, A. (2012), "Determinants of bank long-term lending behavior in the central African economic and monetary community (CEMAC)", Review of Economics and Finance, Better Advances Press, Canada, Vol. 2, pp. 107-114.

Daley, J. and Matthews, K. (2009), Measuring Bank Efficiency: Tradition or Sophistication?-A Note, Cardiff Economics Working Papers, Cardiff, Wales, UK.

Dimitrios, A., Helen, L. and Mike, T. (2016), "Determinants of non-performing loans: evidence from Euro-area countries”, Finance Research Letters, Elsevier, Vol. 18, pp. 116-119, doi: 10.1016/j.frl. 2016.04.008. 
AJAR

5,1

144

Ekanayake, E. and Azeez, A.A. (2015), "Determinants of non-performing loans in licensed commercial banks: evidence from Sri Lanka", Asian Economic and Financial Review. Asian Economic and Social Society, Vol. 5 No. 6, p. 868.

Fiordelisi, F., Marques-Ibanez, D. and Molyneux, P. (2011), "Efficiency and risk in European banking”, Journal of Banking and Finance, Elsevier, Vol. 35 No. 5, pp. 1315-1326.

Fofack, H.L. (2005), Nonperforming Loans in Sub-saharan Africa: Causal Analysis and Macroeconomic Implications, The World Bank, Washington, DC.

Ghosh, A. (2015), "Banking-industry specific and regional economic determinants of non-performing loans: evidence from US states”, Journal of Financial Stability, Elsevier B.V., Vol. 20, pp. 93-104, doi: $10.1016 /$ j.jfs.2015.08.004.

Godlewski, C.J. (2008), "Bank capital and credit risk taking in emerging market economies", Journal of Banking Regulation, Vol. 6 No. 2, pp. 128-145, doi: 10.1057/palgrave.jbr.2340187.

Gujarati, D. and Dawan, C. (2015), Porter, McGraw-Hill Education, Washington, DC.

Handley, N.J. (2010), "Growth in a time of debt”, CFA Digest, Vol. 40 No. 3, pp. 19-20, doi: 10.2469/dig. v40.n3.19.

Hu, J. (2002), "Ownership and loans: evidence from Taiwanese banks and non-performing loans: evidence from Taiwanese banks", Wiley Online Library, Vol. 3, pp. 405-420.

Hu, J., Li, Y. and CHIU, Y. (2004), "Ownership and nonperforming loans: evidence from Taiwan's banks", The Developing Economies, Wiley Online Library, Vol. 42 No. 3, pp. 405-420.

Hue, N.T.M. (2015), "Non-performing loans: affecting factor for the sustainability of vietnam commercial banks", Journal of Economics and Development, Vol. 17 No. 1, pp. 93-106.

Ivanovic, M. (2016), "Determinants of credit growth: the case of montenegro", Journal of Central Banking Theory and Practice, Vol. 5 No. 2, pp. 101-118, doi: 10.1515/jcbtp-2016-0013.

Jameel, K. (2014), "Crucial factors of nonperforming loans evidence from Pakistani banking sector", International Journal of Scientific and Engineering Research, Vol. 5 No. 7, pp. 704-710.

Keeton, W.R. (1999), "Does faster loan growth lead to higher loan losses?", Economic Review-Federal Reserve Bank of Kansas City, Federal Reserve Bank of Kansas City, Vol. 84, pp. 57-76.

Kirui, S. (2014), "The effect of non performing loans on profitability of commercial banks in Kenya", Research Submitted For Master Degree Programme, University of Nairobi, Kenya.

Koju, L., Koju, R. and Wang, S. (2018), "Macroeconomic and bank-specific determinants of nonperforming loans: evidence from Nepalese banking system", Journal of Central Banking Theory and Practice, Vol. 7 No. 3, pp. 111-138, doi: 10.2478/jcbtp-2018-0026.

Kumar, V. and Kishore, M.P. (2019), "Macroeconomic and bank specific determinants of nonperforming loans in UAE conventional bank", Journal of Banking and Finance Management, Vol. 2 No. 1, pp. 1-12.

Louzis, D.P., Vouldis, A.T. and Metaxas, V.L. (2012), "Macroeconomic and bank-specific determinants of non-performing loans in Greece: a comparative study of mortgage, business and consumer loan portfolios", Journal of Banking and Finance, Elsevier B.V., Vol. 36 No. 4, pp. 1012-1027, doi: 10.1016/j.jbankfin.2011.10.012.

Makri, V., Tsagkanos, A. and Bellas, A. (2014), "Determinants of non-performing loans: the case of Eurozone”, Panoeconomicus, Vol. 61 No. 2, pp. 193-206.

Mehmood, B., Younas, Z.I. and Ahmed, N. (2013), "Macroeconomic and bank specific covariates of non-performing loans (NPLs) in Pakistani commercial banks: panel data evidence", Journal of Emerging Economies and Islamic Research, Vol. 1 No. 3, pp. 1-14.

Michael, J.N. (2006), "Effect of non-performing assets on operational efficiency of central co-operative banks", Indian Economic Panorama, Vol. 16 No. 3, pp. 33-34 \& 39.

Moradi, Z.S., Mirzaeenejad, M. and Geraeenejad, G. (2016), "Effect of bank-based or market-based financial systems on income distribution in selected countries", Procedia Economics and Finance, Elsevier B.V., Vol. 36 No. 16, pp. 510-521, doi: 10.1016/s2212-5671(16)30067-3. 
Rachman, R.A., Kadarusman, Y.B., Anggriono, K. and Setiadi, R. (2018), "bank-specific factors affecting non-performing loans in developing countries: case study of Indonesia", The Journal of Asian Finance, Economics and Business (JAFEB), Vol. 5 No. 2, pp. 35-42.

Rajan, R. (1994), "Why bank credit policies fluctuate", The Quarterly Journal of Economics, Vol. 2 No. 109 , pp. 399-441.

Soedarmono, W., Machrouh, F. and Tarazi, A. (2011), "Journal of Asian Economics Bank market power, economic growth and financial stability: evidence from Asian banks", Journal of Asian Economics, Elsevier, Vol. 22 No. 6, pp. 460-470, doi: 10.1016/j.asieco.2011.08.003.

Souza, G.J.D.G. and Feijó, C.A. (2011), "Credit risk and macroeconomic interactions: empirical evidence from the Brazilian banking system", Modern Economy, Vol. 2 No. 5, pp. 910-929, doi: 10.4236/ me.2011.25102.

Stijepović, R. (2014), "Recovery and reduction of non-performing loans - podgorica approach", Journal of Central Banking Theory and Practice, Vol. 3 No. 3, pp. 101-118, doi: 10.2478/jcbtp-2014-0017.

Vouldis, A.T. and Louzis, D.P. (2018), "Leading indicators of non-performing loans in Greece: the information content of macro-, micro- and bank-specific variables", Empirical Economics, Springer Berlin Heidelberg, Vol. 54 No. 3, pp. 1187-1214, doi: 10.1007/s00181-017-1247-0.

\section{Further Reading}

Khan, I. and Ahmad, A. (2017), "Assessing banks internal factors as determinants of non-performing loans: evidence from Pakistani commercial banks”, Journal of Managerial Sciences, Vol. 11 No. 1, pp. 109-125.

\section{Corresponding author}

Muhammad Asif Khan can be contacted at: asif_marwat1439@yahoo.com
Determinants of nonperforming loans 